\title{
Globalization and Labor Force Participation
}

\author{
Stacie Beck \\ Department of Economics, University of Delaware, DE 19719, United States \\ Soodong Park \\ Department of Economics, University of Delaware, DE 19719, United States
}

\begin{abstract}
This study finds evidence that globalization depresses labor force participation via social spending and tax policy. We estimate a panel Vector Auto Regression model on data over the period of 1980 2012 from the 26 OECD countries. Social spending has increased, consistent with the compensation hypothesis, while labor income taxes have risen relative to capital income taxes, consistent with tax competition hypothesis. As a result, one can see the reduction of labor force participation. Social safety nets and tax policies need to be streamlined upon globalization.
\end{abstract}

JEL Classification: H87, F15, F66

Keywords: Fiscal policy, Globalization, Labor force participation, Tax competition, Compensation hypothesis, Panel VAR

\footnotetext{
* Corresponding Author: Stacie Beck; Department of Economics, University of Delaware, Newark, DE, 19716, USA; Email: beck@ udel.edu Phone: (302) 831-1915 Fax: (302)831-6968.

Co-Authors: Soodong Park; Department of Economics, University of Delaware, Newark, DE, 19716, USA; Email: soodong@udel.edu Phone: (302) 831-2566 Fax: (302)831-6968
} 


\section{Introduction}

We uncover the effects of globalization on both tax policy and transfers, i.e., social spending programs, and how changes in their interaction result in depressing labor force participation. Two prominent hypotheses in this area are the tax competition and compensation hypotheses. The tax competition hypothesis states that, when capital becomes internationally mobile, governments strategically cut capital income tax rates to attract neighbors' capital and expand the tax base. Low capital income tax rates reduce tax revenue, causing under-provision of public goods and a welfare crisis. In fact, welfare crises have not occurred. Instead, social expenditures have increased over time in most OECD countries. This observation has led to the compensation hypothesis, according to which governments raise social spending to guard workers against income volatility associated with globalization.

If tax competition causes governments to raise labor taxes in lieu of capital taxes, labor force participation will be reduced. Likewise, high social spending may discourage labor force participation. Our results show support for both channels, however we find that the evidence for the second channel is stronger and more consistent. Moreover, we find evidence that tax competition works through feedback effects by causing governments to finance higher social spending through increases in labor taxes relative to capital taxes.

Empirical studies have investigated the tax competition and compensation hypotheses in separate models. This study extends the research by allowing the possibility of feedback effects between tax policy and social spending. We employ a Panel Vector Auto Regression (PVAR) approach and impose weak exogeneity conditions. We assume our measure of globalization is weakly exogenous. To further investigate the role of globalization we estimate the model on subsamples of data that differ in degree of openness. We split the sample three ways: into EU and non-EU members, into countries with relatively weak and strong capital controls, and into pre-1992 and post-1992 periods. The subsample results support that more open economies experience greater variability in income/output, increases in social spending and a heavier reliance on labor taxes relative to capital income tax for financing social spending. 
In Section 2 we review the literature and set out hypotheses. Sections 3 and 4 describe data collection and model construction. Section 5 reports the empirical results of the baseline model and subsample models. Section 6 offers our conclusions.

\section{Background}

The Zodrow and Mieszkowski (1986) model and its extensions (Bucovetsky 1991, Bucovetsky and Wilson 1991) predict a capital tax race to the bottom and a social spending contraction as a result of globalization. Razin and Sadka (1995) and Eichner and Upmann (2012) also show that optimal capital tax rates are zero in open economies. However, empirical evidence is conflicting on whether globalization has in fact reduced capital taxes. Some authors (Quinn 1997, Swank 1998, Garrett and Mitchell 2001, Dreher 2006) found no associated reduction, whereas others did find reductions (Rodrik 1997, Winner 2005, Bretschger and Hettich 2005, Devereux et al. 2008). Evidence that globalization is associated with increased labor taxes is stronger (Bretschger and Hettich 2005, Winner 2005, Adam and Kammas 2007, Onaran et al. 2011) ${ }^{1}$. The fact that labor tax increases lead to lower labor force participation rates is well established (see Blundell et al. 1998, Prescott 2004, Davis and Henerkson 2004, Simula and Trannoy 2010).

Despite the prediction of reduced social spending by the tax competition hypothesis, social spending has increased in most OECD countries (Cameron 1978, Hicks and Swank 1992). Swank and Steinmo (2002) contend that structural unemployment, generated by globalization, raises social spending. Adam and Kammas (2007) suggest that social spending has increased to compensate for income volatility caused by globalization. In either case, increased social spending may create work disincentives that further reduce labor force participation. Based on this literature, we test three hypotheses:

Tax Competition Hypothesis: An increase in openness reduces the capital-tolabor tax ratio and this reduction lowers the labor force participation rate.

'An exception is Swank and Steinmo (2002) 
Compensation Hypothesis: An increase in openness increases social spending which lowers the labor force participation rate.

Interaction Hypothesis: Increases in social spending increase the labor tax which leads to a lower labor force participation rate.

We use impulse responses from PVAR estimation to determine the validity of these hypotheses over the period of 1980 2012.

\section{Data Collection}

Variables include a measure of globalization (open), average effective capital-to-labor income tax ratio $(t k l)$, share of social transfers and benefits to GDP (social), the output gap (ygap), and the labor force participation rate (lfpr). Data for 26 OECD countries from 1980 to 2012 was collected ${ }^{2}$.

Globalization is measured by Dreher's (2006) KOF economic index. This index includes both qualitative and quantitative aspects. These are 'Actual flows' (trade, foreign direct investment, foreign portfolio investment, and income payments to foreign nationals) and 'Restrictions' (mean tariff rates, taxes on trade, and an index of capital controls). Average effective tax rates measure the capital-to-labor income tax ratio ( $\mathrm{kkl}$ ) (Mendoza et al. 1994, Carey and Rabesona 2002). We employ the methodology of Carey and Rabesona (2002) to construct the tax ratio. The ratio of social transfers and benefits to GDP (social) measures social spending ${ }^{3}$. The output gap variable measures income. The output gap (ygap) is calculated as the deviation of real gross domestic product (RGDP) from its trend. The residuals are extracted by detrending the series using Hodrick and Prescott (HP) filtering. The labor force participation rate (lfpr) is the ratio of labor force to working age population.

The presence of a unit root is tested by the Im-Pesaran-Shin (IPS) panel unit root test. In order to decide whether the residual contains a time trend or

\footnotetext{
${ }^{2} 8$ countries (Chile, Estonia, Hungary, Iceland, Israel, Luxemburg, Mexico, and Turkey) from 34 OECD countries are dropped because the data for effective tax rates are not available.

${ }^{3}$ We experimented with subcategories of social expenditures to check robustness of results. Two subcategories: unemployment and old age pension expenditures, showed similar and strong results whereas results with health care, disability and family expenditures were weaker. These are available from the authors upon request.
} 
not, the test is replicated with an inclusion of a time trend. At the five percent confidence level, ygap and $t k l$ are stationary in level, while open, social, and lfpr are difference stationary of order one ${ }^{4}$. The open, social, and lfpr variables are first differenced, so these variables are now in terms of changes.

Below is a table with summary statistics. Sources are listed in Appendix A3.

Table 1. Summary statistics of main variables

(26 OECD countries, 1980 2012)

\begin{tabular}{|l|c|c|c|c|c|}
\hline Variable & Obs & Mean & Std. Dev & Min & Max \\
\hline Open & 769 & 71.1004 & 14.4854 & 23.88 & 96.83 \\
\hline oppen & 743 & .6881 & 1.9063 & -5.95 & 19.4 \\
\hline ygap & 804 & .0000 & .0684 & -.4457 & .5181 \\
\hline tkl & 652 & .8422 & .3874 & .0138 & 2.6690 \\
\hline social & 604 & 24.9739 & 6.9431 & 4.2885 & 41.9896 \\
\hline$\Delta$ social & 578 & .1641 & 1.0269 & -4.4434 & 5.7937 \\
\hline$l f p r$ & 762 & 71.5668 & 6.4954 & 56.1767 & 84.1474 \\
\hline$\Delta l f p r$ & 736 & .1863 & .6110 & -2.0085 & 3.2299 \\
\hline
\end{tabular}

(Note) (i) The open is KOF economics integration index ranging from 0 to 100.

The ygap is deviation of Real Gross Domestic Product (RGDP) from its trend.

The $t k l$ is average effective capital-to-labor tax ratio.

The social is social transfers and benefits as a share of Gross Domestic Product (GDP).

The lfpr is the share of labor force as a share of working age population.

(ii) Values are rounded at $5^{\text {th }}$ decimal point.

\section{Model Construction}

We employ a PVAR technique to allow the possibility of feedback effects between tax policy and social spending. A reduced-form PVAR of the first order is ${ }^{5}$;

\footnotetext{
${ }^{4}$ The choice of lag length is one, guided by Akaike Information Criterion (AIC) and the test statistics are found to be insensitive up to an inclusion of maximum length of three. We also performed the test proposed by Westerlund (2008). The Westerlund test provides four statistics; $G_{a}, G_{t}, P_{a}$, and $P_{t}$, and . The test statistics of the four variables in level are found to be insignificant at one percent confidence level. We failed to reject the null hypothesis of no cointegration.

${ }^{5}$ The time fixed effect is suppressed by demeaning the series.
} 


$$
\begin{gathered}
Y_{i t}=\Phi Y_{i t-1}+A_{i}+u_{i, t}, u_{i, t} \sim i i d(0, \Sigma) \\
Y_{i t}=(\text { open,ygap, } t k l, \text { social }, \text { lfpr })
\end{gathered}
$$

The $A_{i}$ is a vector of country fixed effects, $\Phi$ is a matrix of coefficients of five endogenous variables, and $u_{i, t}$ is a vector of residuals that are independent and identically distributed. Employing a lagged dependent variable as an instrument suffers from biasness and inconsistency because the fixed effect is correlated to the instrument. That is:

$$
E\left[y_{i t-1} a_{i}\right] \neq 0 \text {, therefore } E\left[y_{i t-1} v_{i, t}\right] \neq 0 \quad \text { where } v_{i, t}=\varepsilon_{i, t}+\alpha_{i}
$$

To eliminate the fixed effect, either first differencing or forward mean differencing could be used ${ }^{6}$. Forward mean differencing, i.e., the Helmert procedure, is used here (Arellano and Bover 1995, Love and Zicchino 2006, Boubtane et al. 2012). The transformation process is:

$$
\ddot{y}_{i t}=\frac{\left(y_{i t}-\bar{y}_{i t}\right)}{\sqrt{\frac{T_{i}-t_{i}+1}{T_{i}-t_{i}}}}, \quad \bar{y}_{i t}=\sum_{s=t+1}^{T} \frac{y_{i, s}}{T-s}
$$

Here, $\bar{y}_{i t}$ is the forward mean of the $y_{i t}$ at time $\mathrm{t}$ and $\ddot{y}_{i t}$ is the transformed variable. Through this transformation, the fixed effect is eliminated and the instrument satisfies the orthogonal condition:

$$
E\left[y_{i t-1} \ddot{\varepsilon}_{i, t}\right]=0 \quad \text { and } \quad E\left[\ddot{y}_{i t} y_{i t-1}\right] \neq 0
$$

Estimation is performed by system GMM (Blundell and Bond 1998, Arellano and Bover 1995). In matrix form, the system GMM is:

$$
\left(\begin{array}{l}
\ddot{y}_{i, t} \\
y_{i, t}
\end{array}\right)=\phi\left(\begin{array}{l}
\ddot{y}_{i, t-1} \\
y_{i, t-1}
\end{array}\right)+\varphi\left(\begin{array}{l}
\ddot{x}_{i, t-1} \\
x_{i, t-1}
\end{array}\right)+\left(\begin{array}{l}
\ddot{\varepsilon_{i, t}} \\
\varepsilon_{i, t}
\end{array}\right)
$$

The coefficient matrix $\Phi$ is estimated by the two-stage, or instrumental variable (IV), GMM.

${ }^{6}$ Bond et al. (2001) argue in favor of the latter to avoid throwing away information embedded in levels and avoid magnifying the gap in an unbalanced panel data. 
The structural form of the model is:

$$
B_{0} Y_{i t}=B(L) Y_{i t}+A^{\prime}{ }_{i}+e_{i, t}
$$

This is recovered from an estimation of the reduced form (1). Thus, $\Phi$ $(L)=\mathrm{B}_{0}^{-1} B(L), A_{i}^{\prime}=\mathrm{B}_{0}^{-1} A_{i}, u_{i, t}=\mathrm{B}_{0}^{-1} e_{i, t}$. We use Choleski decomposition to identify the $B_{0}$ matrix. In our baseline model we use the order: open, output gap, tax ratio, social spending, and labor force participation rate. We also obtain results when the order of output gap, tax ratio and social spending is switched ${ }^{7}$. The weak exogeneity condition is imposed on the open variable reflects the hypothesis that globalization has impacted the behavior of the tax ratio (tax competition) and social spending (compensation hypothesis), hence labor force participation. We regard the assumption as reasonable given the political nature of trade treaties and financial liberalization policies, whereas it is much less likely that the other variables are weakly exogenous vis-a-vis the open variable ${ }^{8}$.

\section{Empirical Results}

\section{A. Baseline model estimation}

A subset of the impulse response functions (IRFs) results appear in Figure 1. A positive standard deviation shock is given at period zero and ninety percent confidence intervals are generated by one thousand replications of Monte Carlo simulation?.

The first set of panels of Figure 1 presents responses to a positive shock from a change in openness. The capital-to-labor tax ratio initially drops from the shock, the response of the tax ratio becomes insignificant shortly thereafter, providing only suggestive evidence of tax competition. The response of the social spending variable is to drop immediately and then, with a delay of two periods, rise above the initial level and stay nearly constant.

\footnotetext{
${ }^{7}$ Results are provided in Appendix A, Figure A.5.

${ }^{8}$ Our assumption also has empirical support from the results of Kim et al. (2018): p.2797.

${ }^{9}$ We modified a program code provided by Love and Zicchino (2006).
} 
We interpret this as stronger evidence for the compensation hypothesis than that for the tax competition hypothesis. In the third set of panels of Figure 1, in response to a positive shock from social spending, the capital-to-labor tax ratio drops, that is, the labor tax rises relative to the capital tax. It support the conjecture that openness leads to higher social spending financed by changes in labor taxes relative to capital taxes. As expected, a decrease in the tax ratio and an increase in social spending have negative impacts on the labor force participation variable.

\section{Figure 1. Baseline model}

\section{Impulse responses to $\Delta$ open shock}

Response of ygap

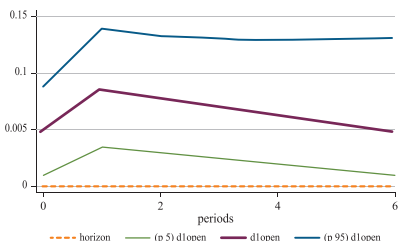

Response of $\Delta$ social

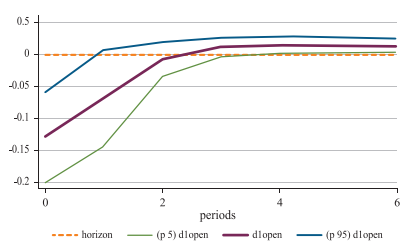

Response of $t k l$

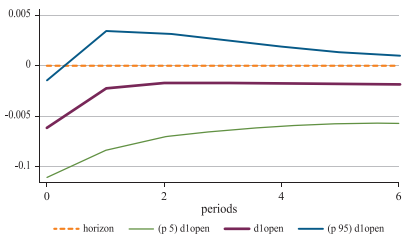

Response of $\Delta l f p r$

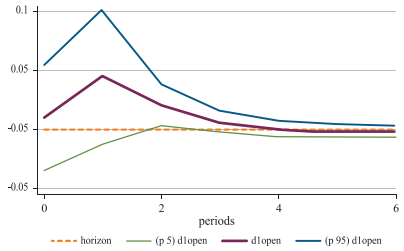

Impulse responses to $t k l$ shock

Response of $\Delta$ open

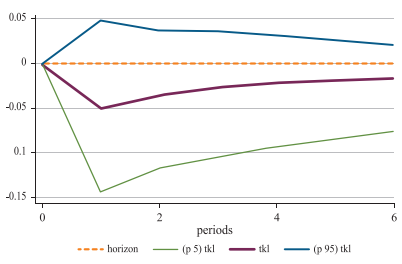

Response of $\Delta y g a p$

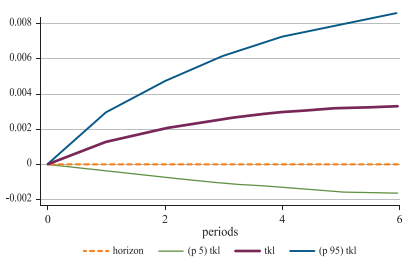




\section{Impulse responses to $t k l$ shock}

Response of $\Delta$ open

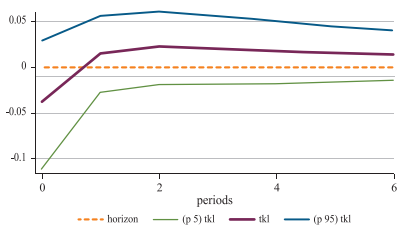

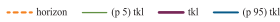

Response of $\Delta y g a p$

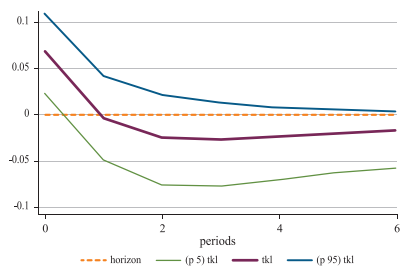

Impulse responses to $\Delta$ social shock

Response of $\Delta$ open

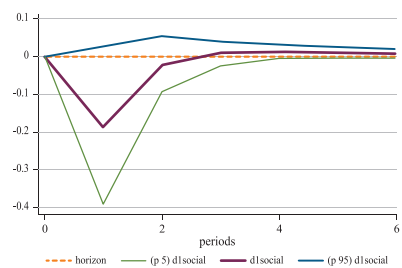

Response of $t k l$

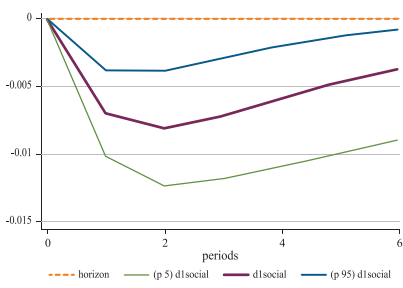

Response of $\Delta y g a p$

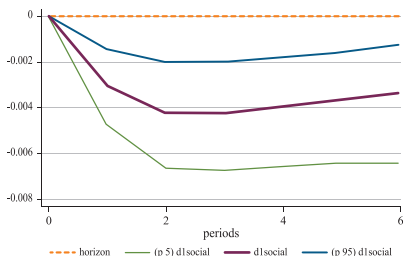

Response of $\Delta l f p r$

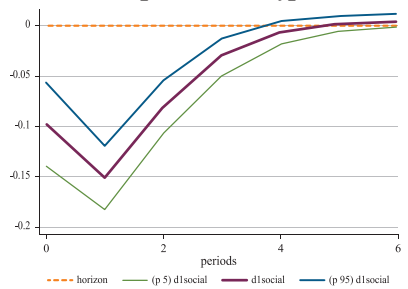

Table 2 reports variance decompositions 10 periods ahead. Variation in the openness, output gap and tax variables are mostly explained by own variation in the long run - 98.1 percent, 94.8 and 95.9 respectively. The shocks on these three variables vanish relatively fast. Variation in the social spending variable is explained, approximately 87.7 percent, by its own, 8.2 percent by the output gap, and 2.2 percent by the openness variable. Variation in the labor force participation rate variable is explained 85.2 percent by its own, 10.8 percent by the social expenditure change, and 2.1 percent by the capital-tolabor tax ratio.

To summarize, a positive shock in openness has a stronger effect on social spending than on the tax ratio, thus supporting the compensation hypothesis 
that globalization raises social spending. Moreover, the impacts of social spending directly on labor force participation and indirectly on the tax ratio suggest that the impact of globalization on the labor market comes more through this channel rather than through changes in tax policy.

Possibly these results are driven by the subset of EU members. To analyze this further, we estimate the model on two subsamples: EU members and nonEU members.

Table 2. Variance decompositon in 10 periods ahead

\begin{tabular}{|c|c|c|c|c|c|}
\hline Variable & sopen & ygap & tkl & $\Delta$ social & $\Delta l f p r$ \\
\hline sopen & .9812 & .0026 & .0013 & .0081 & .0067 \\
\hline ygap & 0331 & .9480 & .0070 & .0100 & .0019 \\
\hline$t k l$ & .0054 & .0129 & .9586 & .0198 & .0033 \\
\hline$\Delta$ social & .0228 & .0820 & .0043 & .8770 & 0139 \\
\hline$\Delta l f p r$ & .0075 & .0101 & .0210 & .1085 & .8529 \\
\hline
\end{tabular}

(Note) ( i ) Variations in row variables are explained by column variables. Values rounded at $5^{\text {th }}$ decimal point

(ii) The open is KOF economics integration index ranging from 0 to 100 .

The ygap is deviation of Real Gross Domestic Product (RGDP) from its trend.

The $t k l$ is average effective capital-to-labor tax ratio.

The social is social transfers and benefits as a share of Gross Domestic Product (GDP).

The $l \mathrm{fpr}$ is the share of labor force as a share of working age population.

(iii) Values rounded at $5^{\text {th }}$ decimal point

\section{B. EU versus Non-EU subsamples}

EU members differ from non-EU members in the degree of openness, which is about 10 points higher than the nonmembers. Because they are more politically integrated than nonmembers, when facing injurious competition, they are more likely to harmonize their tax systems. Additionally, EU members have high levels of social spending (see Table 3). These facts suggest that evidence of tax competition might be less visible in the EU subsample and evidence of the compensation hypothesis stronger.

A subset of IRFs of the subsamples are reported in Figure 2. As expected, the response of the tax ratio variable to a positive shock from the openness 
variable shows no evidence of tax competition in the EU subsample whereas there is slightly stronger evidence for tax competition in the non-EU sample. However, there is a distinct difference in the responses of the social spending variable to a shock in openness. Whereas the response of the non-EU subsample is insignificant, the response of the EU subsample resembles the response in the baseline model. The evidence supporting the compensation hypothesis is stronger in the EU subsample than in the baseline model two periods after the shock.

In neither subsample does a positive shock to the tax ratio (a drop in labor tax) change social spending, but the labor force participation variable significantly increases in the EU subsample, though not significantly in the non-EU subsample. A positive shock to the change in social expenditures permanently lowers the tax ratio, that is, raises the relative tax on labor. This effect is significant over the entire 10 year horizon in the EU subsample but vanishes over time in the non-EU subsample. Moreover, in both groups, an increase in social spending has a negative effect on the labor force participation variable.

Table 3. Summary statistics for EU and Non-EU

\begin{tabular}{|l|c|c|c|c|c|c|}
\hline \multirow{2}{*}{ Variable } & \multicolumn{3}{|c|}{ EU } & \multicolumn{3}{c|}{ Non-EU } \\
\cline { 2 - 7 } & Obs & Mean & Std. Dev & Min & Mean & Std. Dev \\
\hline Open & 521 & 74.1399 & 13.2344 & 248 & 64.7140 & 14.9413 \\
\hline Dopen & 503 & .7640 & 1.9052 & 240 & .5290 & 1.9026 \\
\hline ygap & 540 & .0000 & .0275 & 264 & .0000 & .1128 \\
\hline tkl & 426 & .6791 & .2887 & 226 & 1.1497 & .3626 \\
\hline$\Delta$ social & 419 & 28.0581 & 4.5164 & 185 & 17.9885 & 6.3970 \\
\hline social & 401 & .1772 & 1.095 & 177 & .1344 & .8551 \\
\hline lfpr & 498 & 70.6471 & 6.0394 & 264 & 73.3016 & 6.9663 \\
\hline$\Delta l f p r$ & 480 & .1752 & .6257 & 256 & .2070 & .5831 \\
\hline
\end{tabular}

(Note) (i) EU members are AUT, BEL, CZE, DEN, ESP, FIN, FRA, GER, GRC, IRL, ITA, NLD, POL, PRT, SVK,SVN, SWE, and GBR. Non EU members are AUS, CAN, JAP, KOR, NZL, NOR, CHE, and USA.

(ii) The open is KOF economics integration index ranging from 0 to 100 . The ygap is deviation of Real Gross Domestic Product (RGDP) from its trend. 
The $t k l$ is average effective capital-to-labor tax ratio.

The social is social transfers and benefits as a share of Gross Domestic Product (GDP).

The $l f p r$ is the share of labor force as a share of working age population.

(iii) Values rounded at $5^{\text {th }}$ decimal point

Figure 2. EU and Non-EU

\section{A. Impulse responses to open shock}
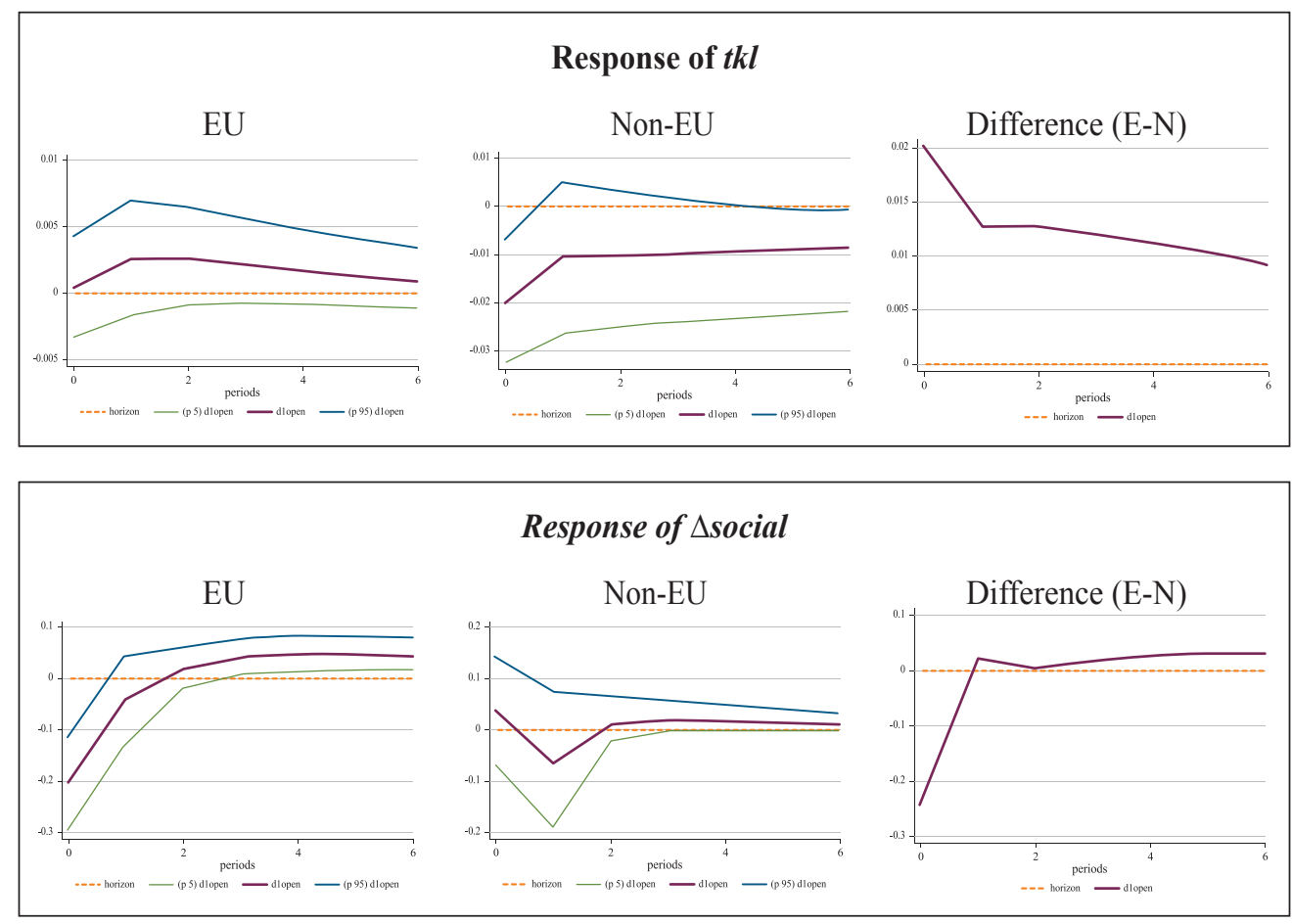

\section{B. Impulse responses to $\Delta t k l$ shock}

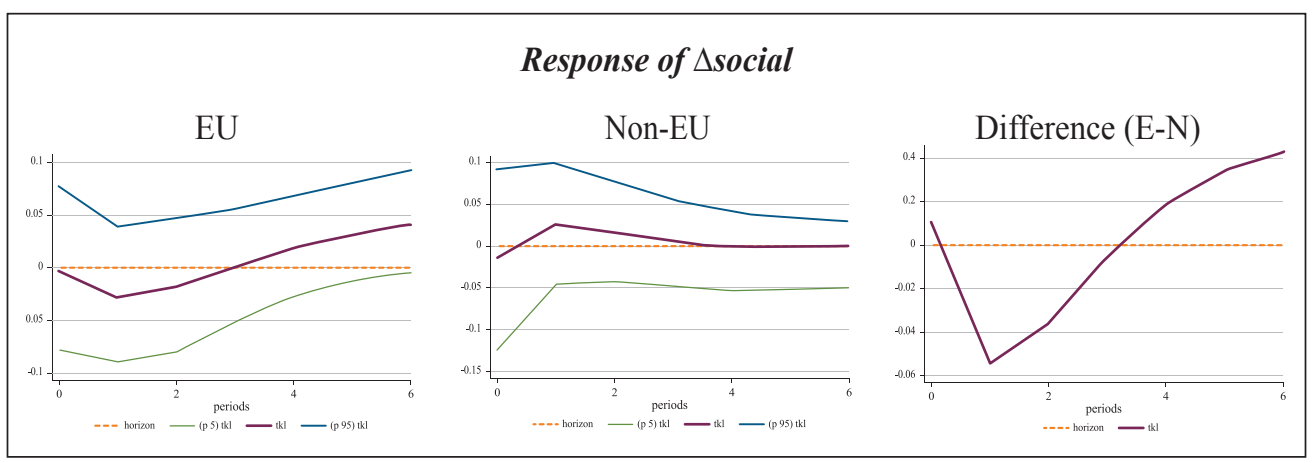




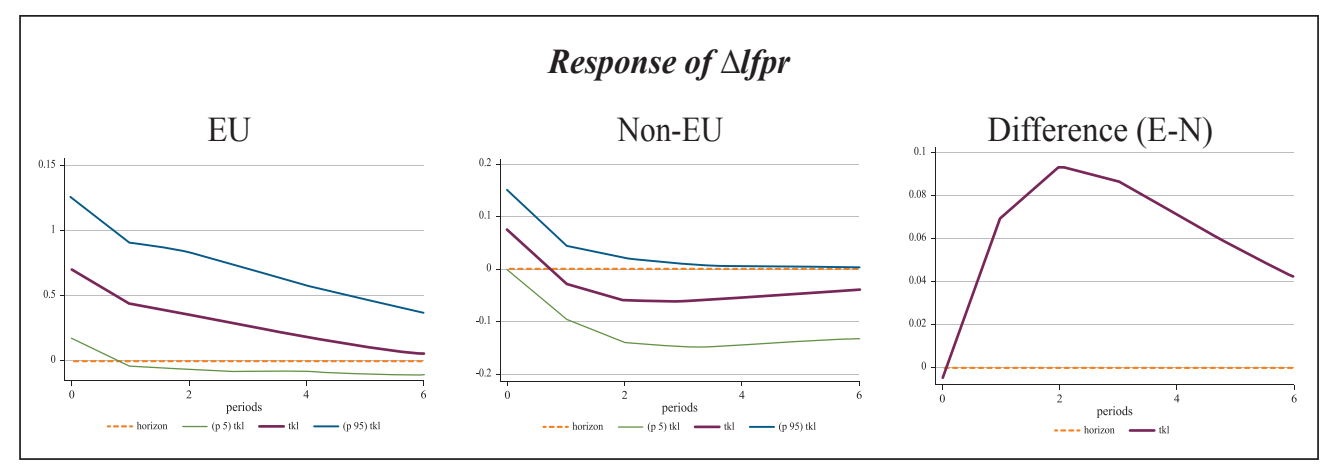

\section{Impulse responses to $\Delta$ social shock}
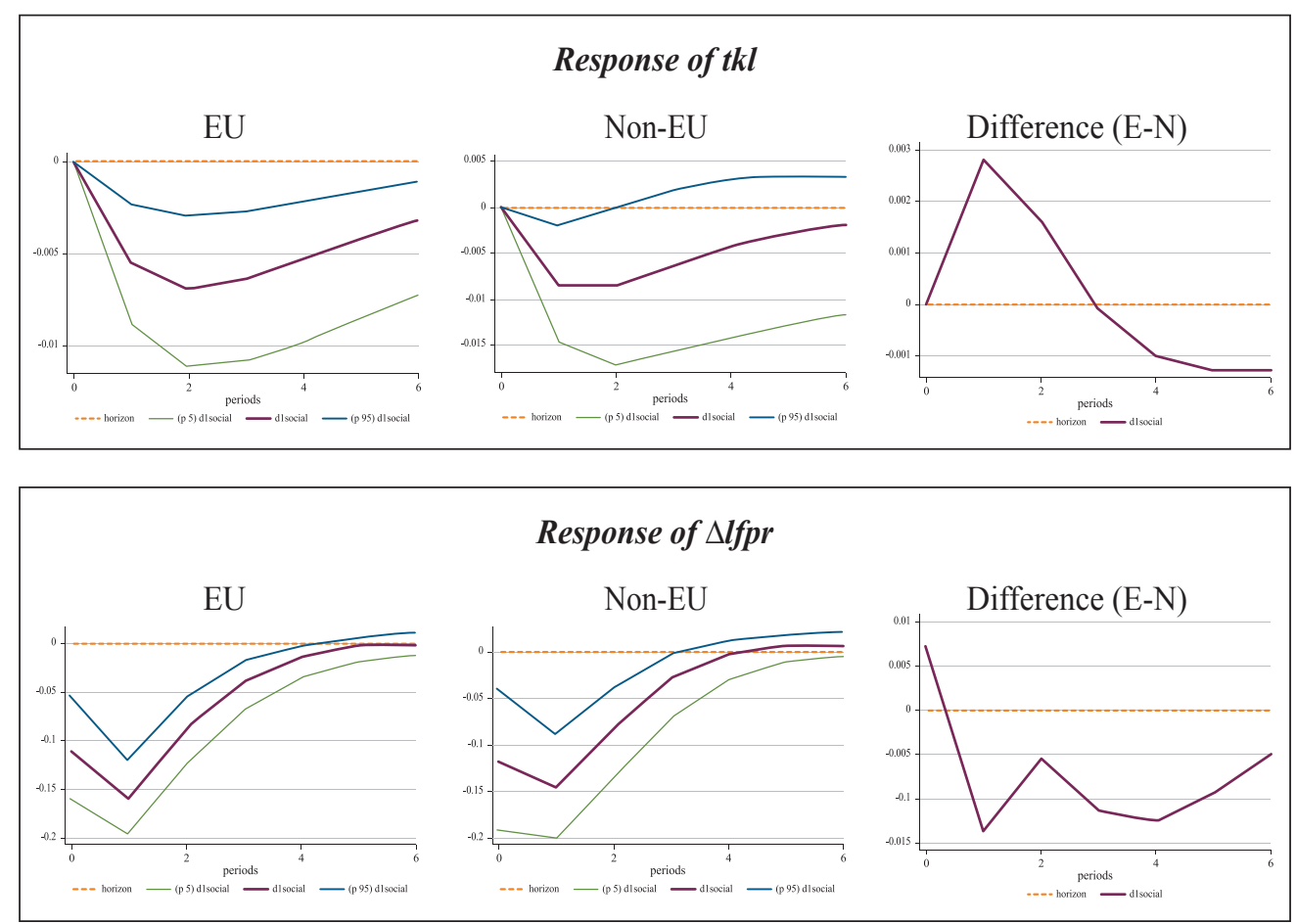

The most noticeable difference in the variance decompositions in Table 4 is in the variations of the social spending variable. Only 58.5 percent of the variation is explained by own variation in the EU subsample whereas it is 85.2 percent for the non-EU subsample and 87.7 percent for the baseline model. The output gap still explains about 36.2 percent of the variations in the social spending variable after 10 periods. 
These results support the idea that, within the EU, the impact of globalization is greater on social spending than on tax competition. However, through feedback effects, the financing burden of higher social spending raises the relative tax on labor. Both relatively higher labor taxes and higher social expenditures have negative impacts on changes in labor participation.

Table 4. Variance decompositon in 10 periods ahead: EU vs. Non-EU

\begin{tabular}{|c|c|c|c|c|c|}
\hline $\mathbf{E U}$ & sopen & ygap & tkl & $\Delta$ social & $\Delta l f p r$ \\
\hline sopen & .9364 & .0355 & .0053 & .0063 & .0164 \\
\hline ygap & .0317 & .8997 & .0373 & .0311 & .0001 \\
\hline$t k l$ & .0063 & .0502 & .8955 & .0474 & .0006 \\
\hline$\Delta$ social & .0401 & .3625 & .0082 & .5853 & .0040 \\
\hline$\Delta l f p r$ & .0068 & .0426 & .0247 & .1207 & .8053 \\
\hline Non-EU & Dopen & ygap & $t k l$ & $\Delta$ social & $\Delta l f p r$ \\
\hline sopen & .9668 & .0035 & .0070 & .0222 & .0005 \\
\hline ygap & .0612 & 9090 & .0031 & .0192 & .0075 \\
\hline$t k l$ & .0375 & .0204 & .9208 & .0074 & .0140 \\
\hline$\Delta$ social & .0104 & .1079 & .0018 & .8525 & .0274 \\
\hline$\Delta l f p r$ & .0220 & .0155 & .0619 & .1199 & .7808 \\
\hline
\end{tabular}

(Note) (i) Variations in row variables are explained by column variables. Values rounded at $5^{\text {th }}$ decimal point

(ii) The open is KOF economics integration index ranging from 0 to 100 .

The ygap is deviation of Real Gross Domestic Product (RGDP) from its trend.

The $t k l$ is average effective capital-to-labor tax ratio.

The social is social transfers and benefits as a share of Gross Domestic Product (GDP).

The $l f p r$ is the share of labor force as a share of working age population.

(iii) Values rounded at $5^{\text {th }}$ decimal point

\section{Capital controls: strong versus weak}

Are capital controls effective in buffering an economy against income volatility thus reducing the need for compensation? Do they insulate an economy from tax competition? We use an index, KAOPEN, developed by Chinn and Ito (2008) to divide the sample by intensity of capital restrictions ${ }^{10}$.

\footnotetext{
${ }^{10}$ The index is based on the 1) presence of multiple change rates, 2) restriction on capital account, 3) restriction on current account, and
} 
After averaging the data from 1996 to 2011, the sample was split in half using a median value of the averages (see Table A5 in the appendix) ${ }^{11}$. The strong control countries are Portugal, Sweden, Spain, Japan, Norway, Belgium, Greece, Czech Rep, Australia, Slovenia, Slovak Rep, Korea, and Poland. The weak control countries are Austria, Canada, Denmark, Finland, France, Germany, Ireland, Italy, Netherlands, New Zealand, Switzerland, United Kingdom, and the United States. Table 5 provides summary statistics of two subsamples.

Table 5. Summary statistics for strong control and weak control

\begin{tabular}{|l|c|c|c|c|c|c|}
\hline \multirow{2}{*}{ Variable } & \multicolumn{3}{|c|}{ Strong Control } & \multicolumn{3}{c|}{ Weak Control } \\
\cline { 2 - 7 } & Obs & Mean & Std. Dev & Min & Mean & Std. Dev \\
\hline Open & 366 & 66.9165 & 16.1223 & 403 & 74.8996 & 11.5953 \\
\hline$\Delta$ open & 353 & .8445 & 2.1821 & 390 & .5465 & 1.6064 \\
\hline ygap & 395 & .0000 & .0406 & 409 & .0000 & .0873 \\
\hline tkl & 284 & .8422 & .4816 & 368 & .8423 & .2957 \\
\hline social & 261 & 23.0269 & 7.7958 & 343 & 26.4554 & 5.8051 \\
\hline$\Delta$ social & 248 & .1483 & 1.0327 & 330 & .1760 & 1.0239 \\
\hline lfpr & 355 & 70.5049 & 5.9222 & 407 & 72.4929 & 6.8304 \\
\hline$\Delta l f p r$ & 342 & .2008 & .6561 & 394 & .1736 & .5695 \\
\hline
\end{tabular}

(Note) (i) Strong countries are AUS, BEL, CZE, ESP, GRC, JAP, KOR, NOR, POL, PRT, SVK, SVN, and SWE. Weak countries are AUT, CAN, DEN, FRA, FIN, GER, ITL, ITA, NLD, NZL, CHE, GBR and USA.

(ii) The open is KOF economics integration index ranging from 0 to 100.

The ygap is deviation of Real Gross Domestic Product (RGDP) from its trend.

The $t k l$ is average effective capital-to-labor tax ratio.

The social is social transfers and benefits as a share of Gross Domestic Product (GDP).

The $l f p r$ is the share of labor force as a share of working age population.

(iii) Values rounded at $5^{\text {th }}$ decimal point

Figure 3 reports a subset of the group comparison results. As can be seen

4) requirement of surrender of export proceeds. The variables are reported in the IMF's annual report on Exchange Arrangement and Exchange Restrictions (AREAER)

"Since countries are members of OECD, hence, highly developed, deviations of one from another are not significantly different. Potentially, large clustering around the median value can result in biasness when splitting the groups. 
from the first line of the set, an increase in openness has no influence or weak influence on the output gap in the strong control group but a significant positive impact on the weak control group. Evidence of tax competition is only observed in the strong control group, suggesting that strong capital controls are not effective at avoiding tax competition. In the strong control group, no evidence of the compensation hypothesis is detected, however the social spending variable initially drops then permanently rises in the weak control group.

A positive output gap shock raises labor force participation in the strong capital control countries, whereas weak capital control countries show a relatively weak positive response after a year, which becomes negative in the long run.

A positive shock in the tax ratio, i.e., drop in labor tax rate, has different responses in social spending and labor force participation between groups. There is an immediate positive impact on labor force participation in the strong control group. In the weak control group there is an increase in social spending but a year's delay in the response of labor force participation.

In both groups, a positive shock to social spending variable raises the labor tax burden. While the burden vanishes relatively quickly in the strong control group, it is long-lasting in the weak control group. A positive shock in social spending has a stronger negative impact on labor force participation in the weak control group than the strong control group.

\section{Figure 3. Strong and weak controal}

\section{A. Impulse responses to Aopen shock}

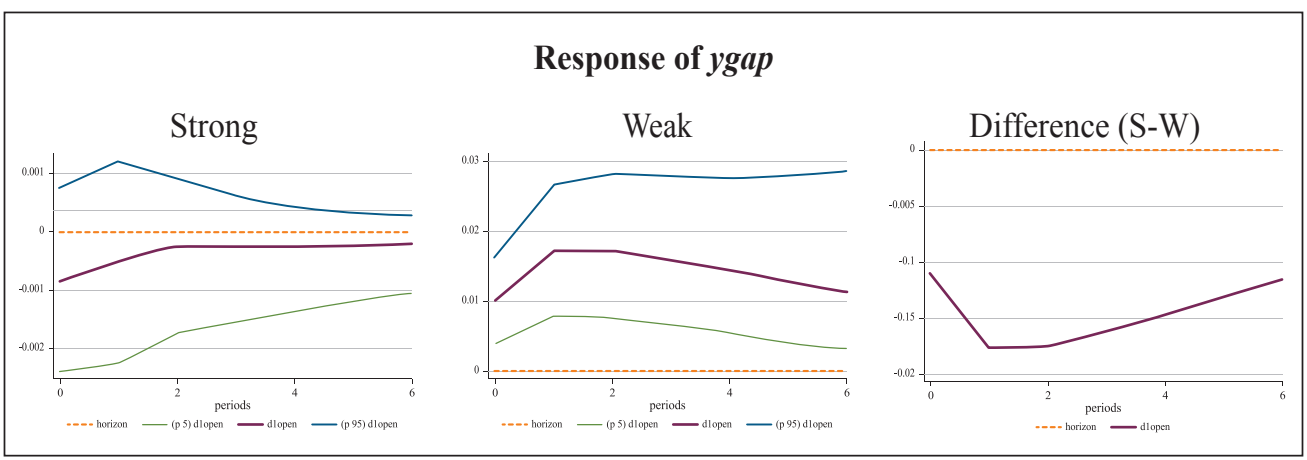



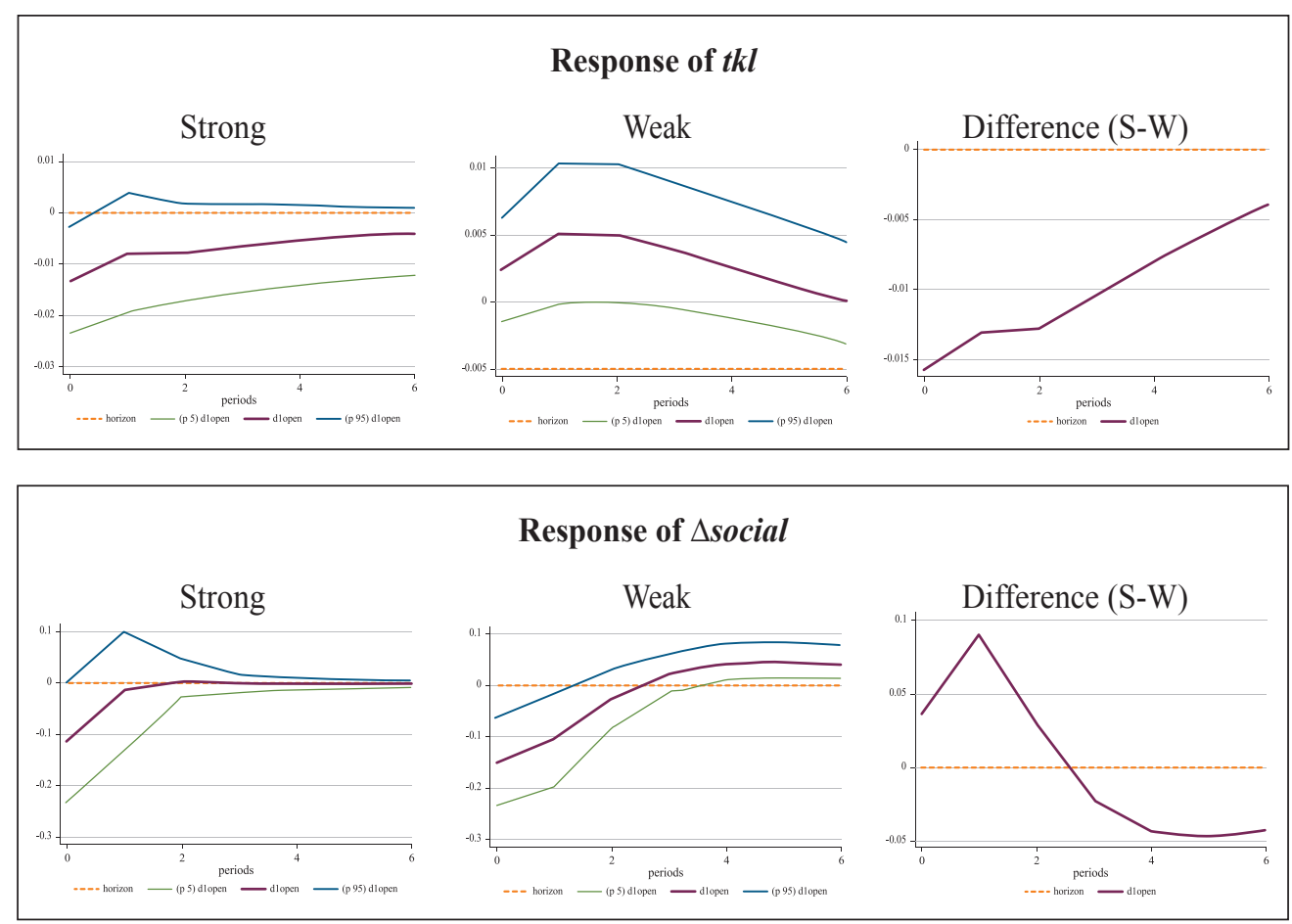

\section{B. Impulse responses to ygap shock}

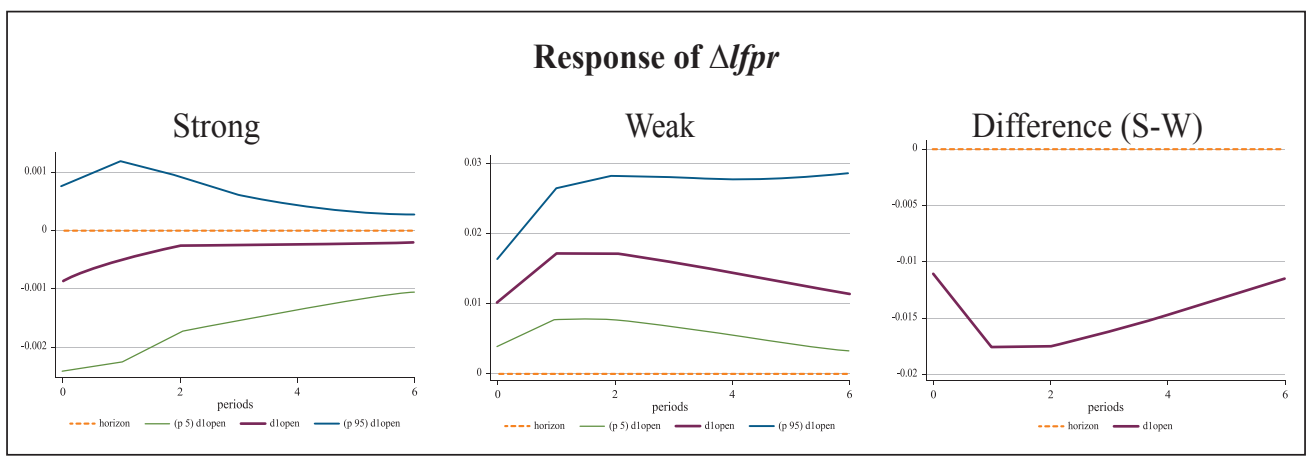




\section{Impulse responses to $t k l$ shock}
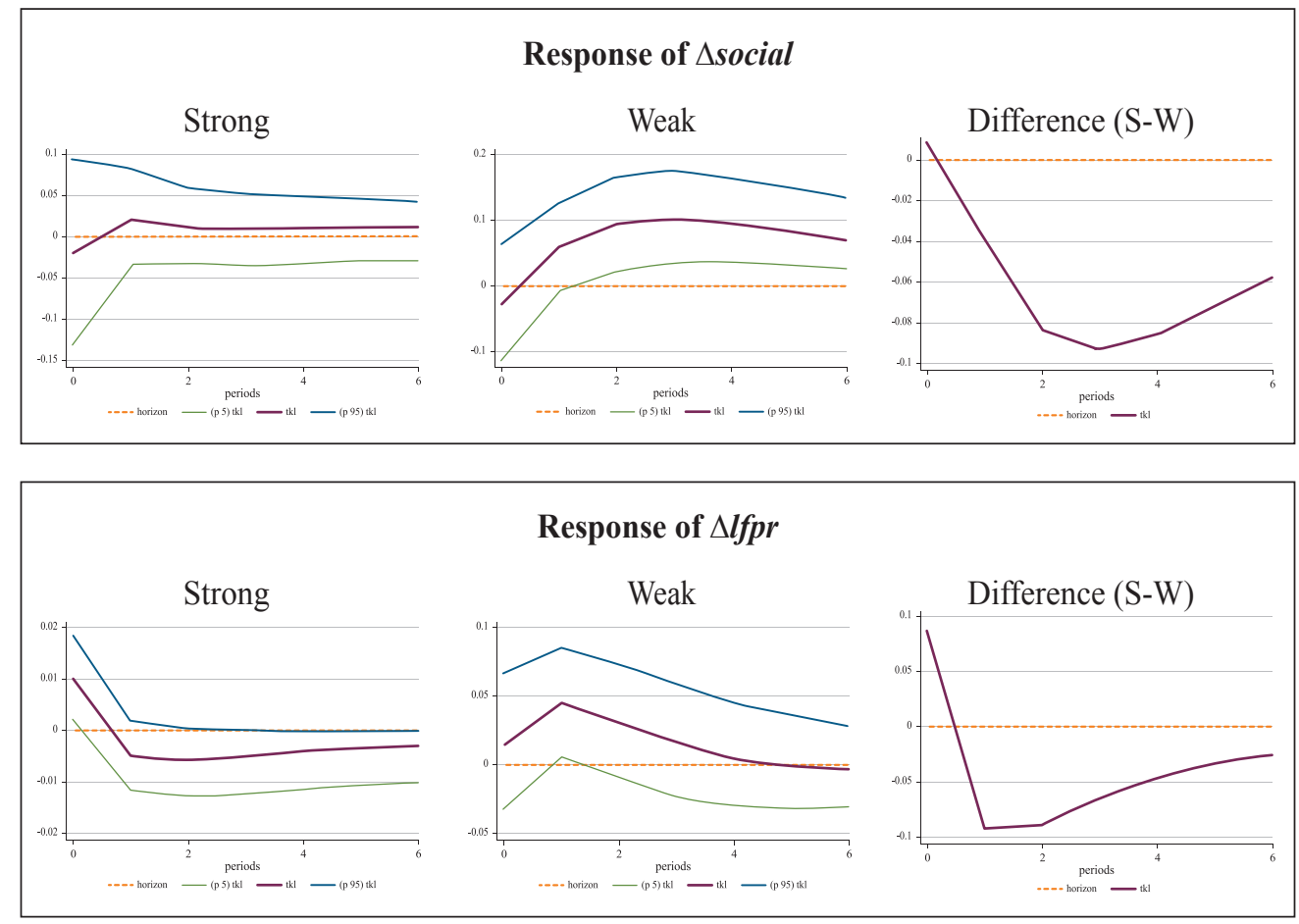

\section{Impulse responses to $\Delta$ social shock}

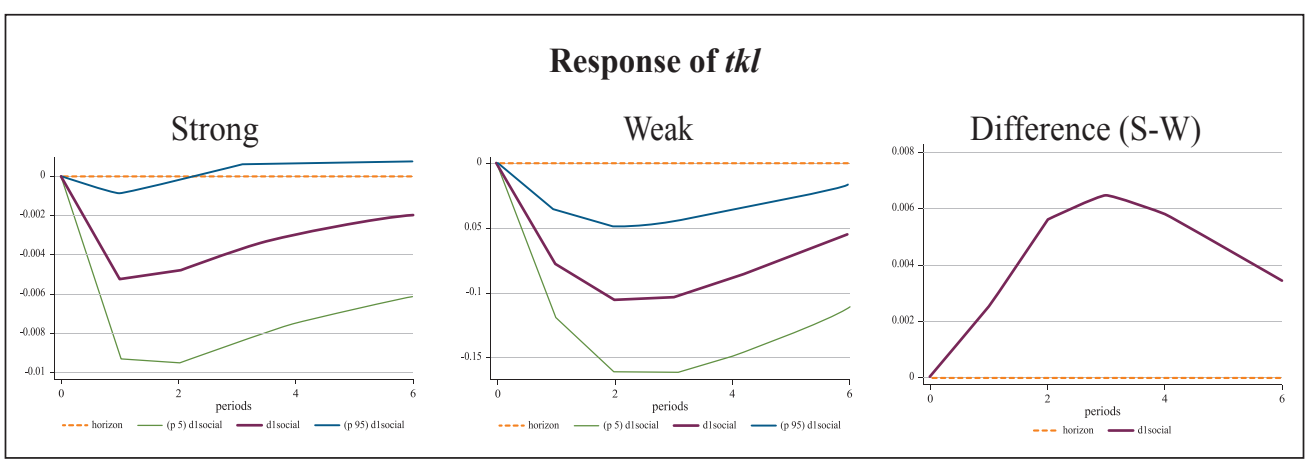




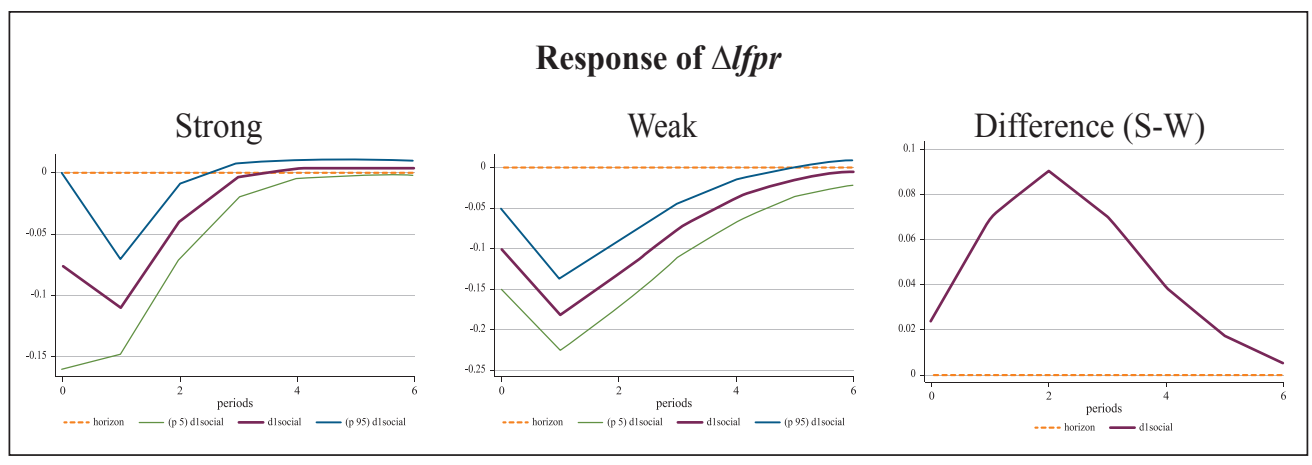

Table 6 shows differences in the variance decompositions for the tax ratio and social spending variables between groups. More of the variation in the tax ratio is explained by the output gap and social expenditure variables in the weak control group. Likewise, more of the variation in social spending is explained by the output gap, tax ratio and openness variables in the weak control group.

Table 6. Variance decompositon in 10 periods ahead: strong vs. weak

\begin{tabular}{|c|c|c|c|c|c|}
\hline Strong & sopen & ygap & tkl & Asocial & $\Delta l f p r$ \\
\hline sopen & .9761 & .0024 & .0059 & .0153 & .0004 \\
\hline ygap & .0033 & .9364 & .0418 & .0128 & .0057 \\
\hline$t k l$ & .0189 & .0022 & .9666 & .0038 & .0085 \\
\hline$\Delta$ social & .0146 & .1134 & .0020 & .8568 & .0132 \\
\hline$\Delta l f p r$ & .0209 & .0457 & .0517 & .0438 & .8380 \\
\hline Weak & sopen & ygap & tkl & Asocial & $\Delta l f p r$ \\
\hline sopen & .9566 & .0097 & .0040 & .0024 & .0273 \\
\hline ygap & .0960 & .8832 & .0050 & .0092 & .0067 \\
\hline$t k l$ & .0158 & .0660 & .8333 & .0845 & .0005 \\
\hline$\Delta$ social & .0419 & .0954 & .0507 & .8011 & .0110 \\
\hline$\Delta l f p r$ & .0079 & .0288 & .0109 & .2067 & .7457 \\
\hline
\end{tabular}

(Note) (i) Variations in row variables are explained by column variables.

(ii) The open is KOF economics integration index ranging from 0 to 100.

The ygap is deviation of Real Gross Domestic Product (RGDP) from its trend.

The $t k l$ is average effective capital-to-labor tax ratio. 
The social is social transfers and benefits as a share of Gross Domestic Product (GDP).

The $l \mathrm{fpr}$ is the share of labor force as a share of working age population.

(iii) Values rounded at $5^{\text {th }}$ decimal point

In summary, countries with weaker capital controls show significant increases in social spending as a result of an increase in openness, and less willingness to raise capital taxes relative to labor taxes as a result of positive shocks to changes in social spending. Positive shocks to social spending have a stronger negative impact on labor participation in countries with weak capital controls. Moreover, while changes in openness have stronger impacts on the output gap in countries with weaker controls, positive output gap shocks seem to have fainter positive impacts on labor force participation in these economies, and even a long run negative effect. The one riddle in this set of results is that increases in the tax ratio (increase in capital tax and/or drop in labor tax) are associated with positive changes in social spending in countries with weak capital controls.

\section{Pre-1992 versus post-1992}

The pre-1992 and post-1992 periods are before and after the greatest wave of globalization. The early $90 \mathrm{~s}$ and late $80 \mathrm{~s}$ are characterized by the formation of the EU, the dissolution of Soviet Union and the emergence of new market-based economies. These developments lowered international uncertainty, increased information flow, and accelerated capital flow across borders. How were the responses of social spending and tax policy changed? We expect the output gap to be positively affected by increases in openness. We also expect to see larger responses of social spending and tax ratios to changes in openness as governments adapt to globalization. We follow Rademacher (2013) who employs 1992 as a structural break point. From Table 7, it can be seen that openness index is about 12 points higher. 
Table 7. Summary statistics for pre-1992 and post-1992

\begin{tabular}{|l|c|c|c|c|c|c|}
\hline \multirow{2}{*}{ Variable } & \multicolumn{3}{|c|}{ Pre-1992 } & \multicolumn{3}{c|}{ Post-1992 } \\
\cline { 2 - 7 } & Obs & Mean & Std. Dev & Min & Mean & Std. Dev \\
\hline \multirow{2}{*}{ Open } & 277 & 63.3883 & 14.0395 & 492 & 75.4419 & 12.8438 \\
\hline Dopen & 253 & .9305 & 1.5018 & 490 & .5629 & 2.0750 \\
\hline ygap & 266 & .0011 & .0519 & 538 & .0000 & .0753 \\
\hline tkl & 209 & .9590 & .4625 & 443 & .7871 & .3330 \\
\hline social & 108 & 22.6076 & 8.5071 & 496 & 25.4891 & 6.4493 \\
\hline$\Delta$ social & 93 & .2950 & .9372 & 485 & .1390 & 1.0423 \\
\hline lfpr & 230 & 69.7318 & 6.7842 & 532 & 72.3600 & 6.2070 \\
\hline$\Delta l$ fpr & 210 & .1710 & .6675 & 526 & .1924 & .5875 \\
\hline
\end{tabular}

(Note) (i) The open is KOF economics integration index ranging from 0 to 100.

The ygap is deviation of Real Gross Domestic Product (RGDP) from its trend.

The $t k l$ is average effective capital-to-labor tax ratio.

The social is social transfers and benefits as a share of Gross Domestic Product (GDP).

The $l \mathrm{fpr}$ is the share of labor force as a share of working age population.

(ii) Values rounded at $5^{\text {th }}$ decimal point

Figure 4 reports a subset of the IRFs of two groups. In the first set of the panels of Figure 4, a positive shock to openness significantly and positively impacts the output gap in the post-1992 period whereas no significant relationship is detected in the pre-1992 period. In the second line of the set, the tax ratio drops in response to the openness shock in the post-1992 period, providing clearer evidence of tax competition. As in the baseline model, the social spending variable rises above the initial level after two periods in the post-1992 period, though here it is not significant.

A positive shock in the tax ratio (high capital tax/low labor tax) increases social spending in the pre-1992 period, however the sign reverses in the post-1992. An increase in the relative tax ratio results in an initial positive response in labor force participation in the post-1992 period but not in the pre-1992 period.

Changes in social spending have no significant impact on the tax ratio in the pre-1992 period, but a negative and significant response is detected in the post-1992 period. The first line of the third set of panels indicate that there 
has an increase in the relative tax burden on labor. Taken with first line of second set of panel, a negative interaction between social spending changes and tax ratio is observed in the post-1992 period. Positive changes in social spending raise the labor tax and vice versa. Through their interaction, the participation in the labor market is reduced.

\section{Figure 4. Pre-1992 and post-1992}

\section{A. Impulse responses to $\Delta$ open shock}
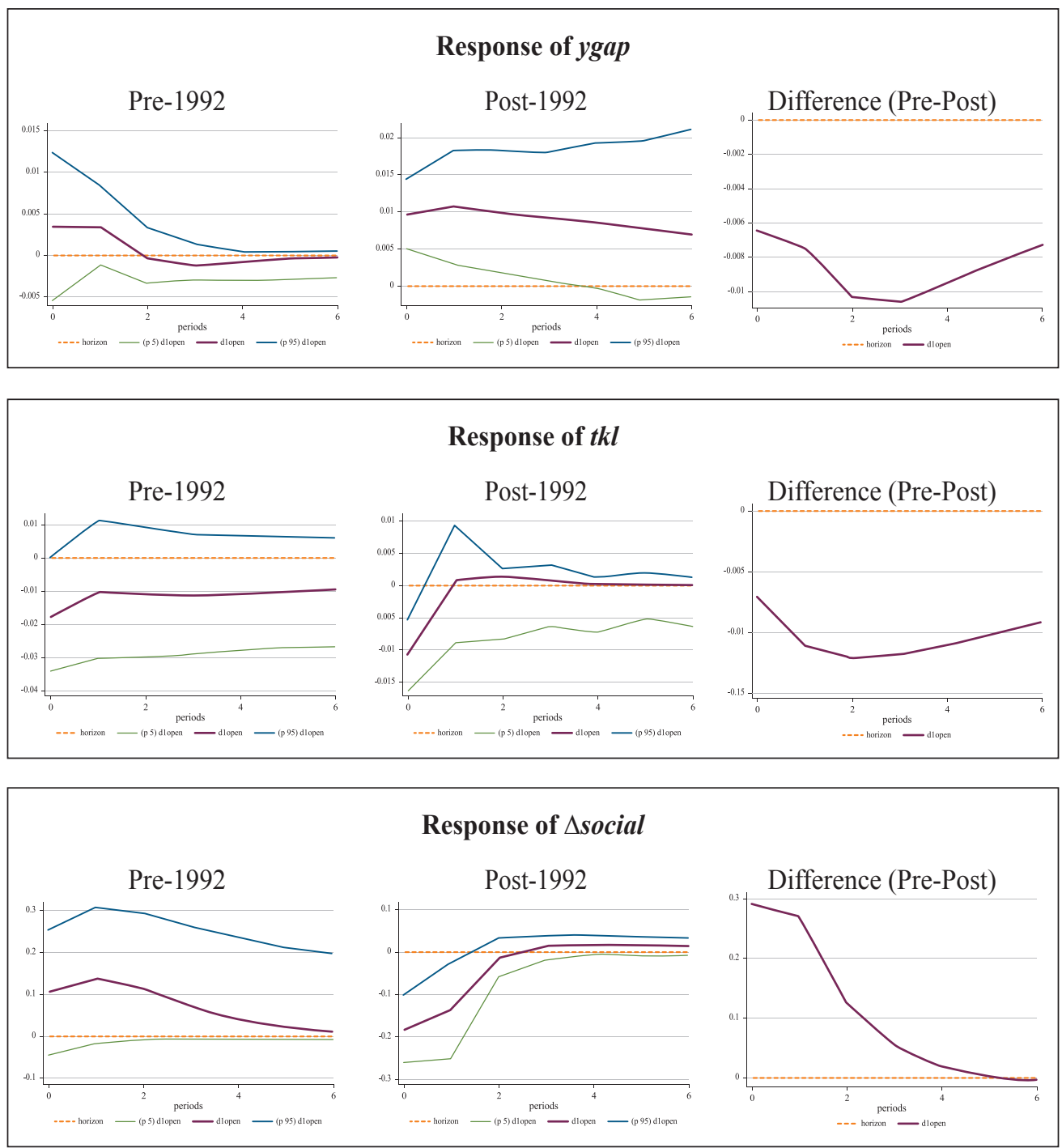


\section{B. Impulse responses to $t \boldsymbol{k} l$ shock}
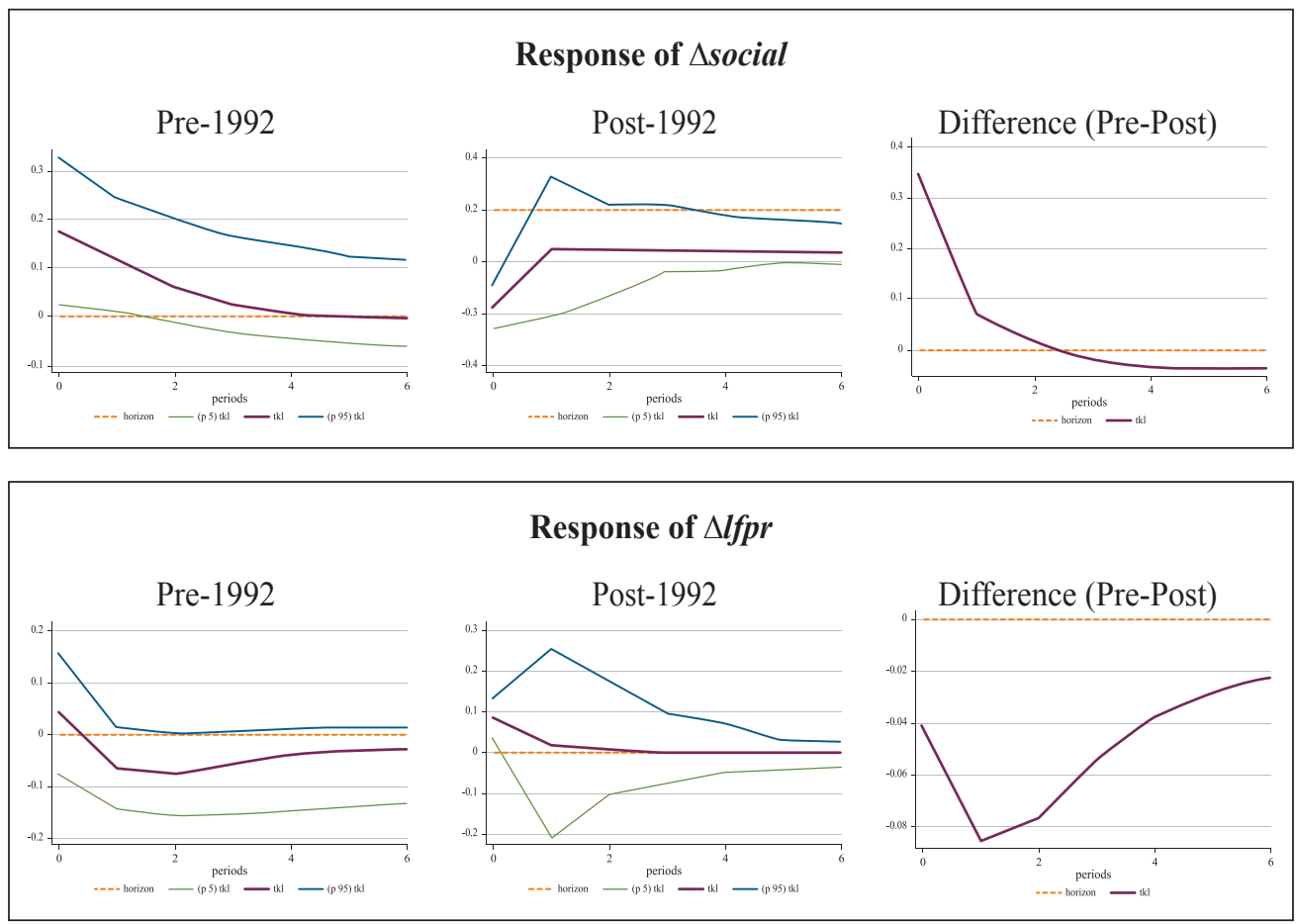

\section{Impulse responses to $\Delta$ social shock}

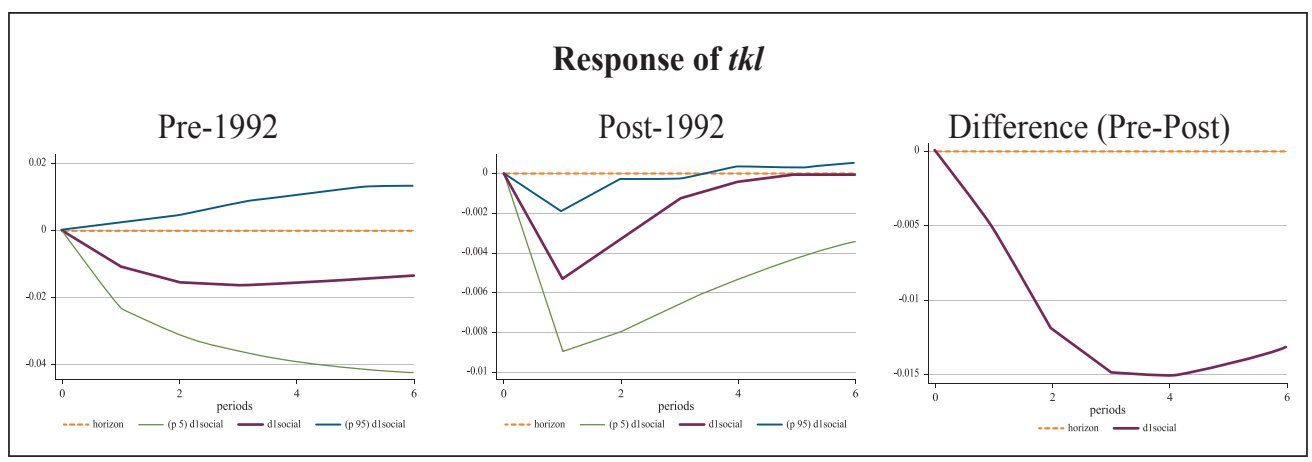




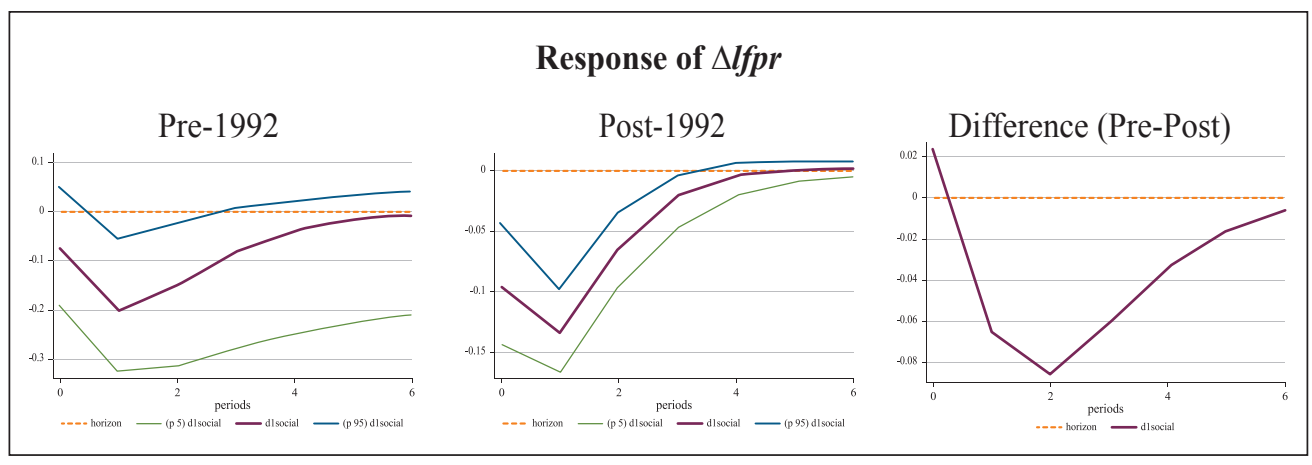

Table 8 reports variance decompositions. The variance of the output gap that is contributed by its own shock drops from 92.9 to 71.3 percent due to increased influence from the openness variable (from 1.1 to 4.5 percent) and tax ratio variable (from 0.8 to 22.3 percent) and there is an increase in the persistence of social spending in the post-1992 period.

Table 8. Variance decompositon in 10 periods ahead: pre-1992 vs. post-1992

\begin{tabular}{|l|c|c|c|c|c|}
\hline \multicolumn{1}{|c|}{ EU } & Dopen & ygap & tkl & $\Delta$ social & $\Delta$ lfpr \\
\hline open & .9414 & .0002 & .0194 & .0066 & .0323 \\
\hline ygap & .0115 & .9299 & .0084 & .0499 & .0003 \\
\hline tkl & .0318 & .0070 & .9003 & .0447 & .0162 \\
\hline social & .0448 & .0685 & .0435 & .8430 & .0002 \\
\hline lfpr & .0096 & .0172 & .0401 & .1542 & .7790 \\
\hline \multicolumn{1}{|c|}{ Non-EU } & $\Delta$ open & ygap & tkl & $\Delta$ social & $\Delta$ lfpr \\
\hline open & .9431 & .0085 & .0280 & .0139 & .0065 \\
\hline ygap & .0459 & .7137 & .2237 & .0123 & .0044 \\
\hline tkl & .0292 & .0332 & .9237 & .0102 & .0038 \\
\hline social & .0568 & .0564 & .0467 & .8232 & .0169 \\
\hline lfpr & .0125 & .0088 & .0222 & .0914 & .8652 \\
\hline
\end{tabular}

(Note) (i)Variations in row variables are explained by column variables.

(ii) The open is KOF economics integration index ranging from 0 to 100.

The ygap is deviation of Real Gross Domestic Product (RGDP) from its trend.

The $t k l$ is average effective capital-to-labor tax ratio.

The social is social transfers and benefits as a share of Gross Domestic Product (GDP). 
The $l f p r$ is the share of labor force as a share of working age population.

(iii) Values rounded at 5 th decimal point

Shocks to openness have stronger positive impacts on the output gap variable in the more open post-1992 period. There is also evidence that openness plays a role in decreasing the tax ratio in the post-1992 period. Openness decreases social spending initially but there is some indication that it increases later. This is consistent with the results of the previous subsection on weak and strong capital controls. There is also evidence that countries reduce the relative tax ratio (raise labor taxes relative to capital taxes) in response to positive changes in social spending in the more open post-1992 period.

\section{Conclusion}

International economic integration has had a profound impact on the workings of national economies, including labor markets. This study uses a PVAR approach that imposes weak exogeneity conditions to gain insight on these effects. Additional insights were gained by estimating the model on subsamples of data that differed by extent of economic integration.

Hypotheses from two prominent models, the tax competition model and the compensation model, are tested. We test whether openness causes countries to raise labor taxes rather than capital taxes, leading to lower labor participation, consequently the need for higher social spending. We also test whether countries seek to shield their populations from income volatility by increasing social spending, which leads to relatively higher labor tax burdens.

Our results support for both channels. However, the evidence for the second channel, i.e., increases in openness directly affect changes in social spending (compensation hypothesis), is stronger and more consistent across samples. Tax competition appears to have worked in an indirect way by causing governments to raise labor taxes relative to capital taxes to finance higher social spending. Both results negatively affect labor force participation in the domestic economy.

Output gap shocks tend to cause greater changes in social spending and higher labor taxes in open economies, which leads to less labor force participation. These labor market effects of globalization via tax and transfer 
policies illustrate that the challenging fiscal reforms are necessary.

Received 11 July 2018, Revised 22 August 2018, Accepted 27 August 2018

\section{References}

Adam A. and Kammas P., "Tax policies in a globalized world: Is it political after all?" Public Choice 133(3) (2007): 321-341.

Arellano M. and Bover O., "Another look at the instrumental variable estimation of error-components models." Journal of Econometrics 68(1) (1995): 29-51.

Blundell R. and Bond S, "GMM estimation with persistent panel data: An application to production function." The institute for fiscal studies working paper 99/4 (1998)

Blundell R., Duncan A. and Meghir C., "Estimating labor supply responses using tax reforms." Econometrica 66(4) (1998): 827-861.

Bond S., Hoeffler A., and Temple J., GMM estimation of empirical growth models. University of Oxford 2001-W21 (2001).

Boubtane E., Coulibaly D. and Rault C., "Immigration, growth, and unemployment; panel VAR evidence from OECD countries." IZA Discussion Paper 6966 (2012).

Bretschger L. and Hettich F., "Globalization and international tax competition: Empirical evidence based on effective tax rates." Journal of Economic Integration 20(3) (2005): 530-542.

Bucovetsky S., “Asymmetric tax competition.” Journal of Urban Economics 30 
(1991): 167-181.

Bucovetsky S. and Wilson J. D., "Tax competition with two tax instruments." Regional Science and Urban Economics 21 (1991): 335-350.

Cameron D. R., "The expansion of public economy: A comparative analysis." The American Political Science Review 72(4) (1978): 1243-1261.

Carey D. and Rabesona J., "Tax ratios on labor and capital income and on consumption.” OECD Economic Studies 35 (2002): 129-174.

Chin M. and Ito H., "A new measure of financial openness." Journal of Comparative Policy Analysis 10(3) (2008): 309-322.

Davis S. J. and Henerkson M., "Tax effects on work activity, industry mix and shadow economy size: Evidences from rich-country comparisons." NBER Working Paper 10509 (2004).

Devereux M., B. Lockwood and M. Redoano., "Do countries compete over corporate tax rates?" Journal of Political Economy 92 (2008): 1210-1235.

Dreher A., "The influence of globalization on taxes and social policy; an empirical analysis for OECD countries." European Journal of Political Economy 22 (2006): 179-201.

Eichner T. and Upmann T., "Labor markets and capital tax competition." International Tax and Public Finance 19 (2012): 203-215.

Garrett G. and Mitchell D., "Globalization, government spending and taxation in the OECD” European Journal of Political Research 39 (2001): 145-177.

Hicks A. M. and Swank D. H., "Politics, institutions, and welfare spending in industrialized democracies, 1960-82." The American Political Science Review 86(3) (1992): 657-674. 
Im K., Pesaran M. H. and Shin Y., "Testing for unit roots in heterogeneous panels." Journal of Econometrics 115(1) (2003): 53-74.

Kim D., Suen Y., Lin S. and Hsieh J., "Government size, government debt and globalization" Applied Economics 50(25) (2018): 2792-2803.

Love I. and Zicchino L., "Financial development and dynamic investment behavior: Evidence from panel VAR." The Quarterly Review of Economics and Finance 46 (2006): 190-210.

Mendoza E. G., Razin A. and Tesar L. L., "Effective tax rates in macroeconomics; cross-country estimates of tax rates on factor income and consumption." Journal of Monetary Economics 34 (1994): 297-323.

Mieszkowski P. and Zodrow G. R., "Taxation and the Tiebout model: The differential effects of head taxes, taxes on land rents, and property taxes." Journal of Economic Literature 27(3) (Sep 1989): 1098-1146.

Onaran O., Bosch V. and Leibrecht M., "How does globalization affect the tax burden on labor income, capital income and consumption in different welfare regimes?” Discussion Papers SFB International Tax Coordination 35 (2011).

Prescott E. C., "Why do Americans work so much more than Europeans?" Federal Reserve Bank of Minneapolis Quarterly Review 28(1) (2004): 2-13.

Quinn D., "The correlates of change in international finance regulation." American Political Science Review 91(3) (1997): 531-551.

Rademacher I., "Tax competition in the Euro-zone." MPIFG Discussion Paper (2013).

Razin A. and Sadka E., "The status of capital income taxation in the open economy." Public Finance Analysis 52(1) (1995): 21-32. 
Razin A. and Sadka E., "Capital income taxation in the globalized world." NBER Working Paper 10630 (2004).

Rodrik D., "Trade, social insurance, and the limits of globalization." NBER Working Paper 5905 (1997).

Simula L. and Trannoy A., "Optimal income tax under the threat of migration by top-income earners." Journal of Public Economics 94 (2010): 163-173.

Swank D., "Funding the welfare state: Globalization and the taxation of business in advanced market economies." Political Studies 46(4) (1998): 671692.

Swank D. and Steinmo S., "The new political economy of taxation in advanced capitalist democracies." Midwest Political Science Association 46(3) (2002): 642-655.

Winner H., "Has tax competition emerged in OECD countries? evidences from panel data." International Tax and Public Finance 12(2005): 667-687.

Westerlund J. and Persyn D., "Error correction based cointegration tests for panel data." Stata Journal 8(2) (2008): 232-241. 


\section{Appendix}

Table A1: Statistics for IPS panel unit root test

\begin{tabular}{|c|c|c|c|c|c|c|}
\hline \multirow[b]{2}{*}{ Level } & \multicolumn{3}{|c|}{ Without Trend } & \multicolumn{3}{|c|}{ With Trend } \\
\hline & $t$-statistic & $P$-value & $\begin{array}{c}\text { AIC } \\
(\max )\end{array}$ & $t$-statistic & $P$-value & $\begin{array}{c}\text { AIC } \\
(\max )\end{array}$ \\
\hline Open & -1.1736 & .1203 & $.77(3)$ & 4.8329 & 1 & $.73(3)$ \\
\hline ygap & -6.1719 & $0000 * * *$ & $1.35(3)$ & -1.7731 & $.0381 * *$ & $1.15(3)$ \\
\hline$t k l$ & -2.9261 & $.0017 * * *$ & $.88(3)$ & -3.0277 & $.0012 * * *$ & $.46(3)$ \\
\hline social & -.7484 & .2271 & $.81(3)$ & -1.1884 & .1173 & $.69(2)$ \\
\hline$l f p r$ & 1.0716 & .8580 & $1.12(3)$ & -.2122 & .4160 & $1.42(3)$ \\
\hline First Diff. & t-statistic & $P$-value & $\begin{array}{c}\text { AIC } \\
(\max )\end{array}$ & $t$-statistic & $P$-value & $\begin{array}{c}\text { AIC } \\
(\max )\end{array}$ \\
\hline sopen & -14.4274 & $.0000 * * *$ & $.58(3)$ & -14.8706 & $.0000 * * *$ & $.5(3)$ \\
\hline$\Delta$ social & -12.0756 & $.0000 * * *$ & $.27(3)$ & -10.5909 & $.0000 * * *$ & $.38(1)$ \\
\hline$\Delta l f p r$ & -10.8326 & $.0000 * * *$ & $.62(3)$ & -9.8156 & $.0000 * * *$ & $.73(3)$ \\
\hline
\end{tabular}

(Note) H0: All panels contain unit root. H1: Some panels are stationary. $* * * 1 \%, * * 5 \%, * 10 \%$

Table A2: Statistics for Westerlund panel cointegration test

\begin{tabular}{|c|c|c|c|c|c|}
\hline Statistics & $\boldsymbol{Z}$-value & $\boldsymbol{P}$-value & Statistics & $\boldsymbol{Z}$-value & $\boldsymbol{P}$-value \\
\hline$G_{a}$ & 6.154 & 1 & $P_{a}$ & 3.501 & 1 \\
\hline$G_{t}$ & 4.499 & 1 & $P_{t}$ & 2.175 & .985 \\
\hline
\end{tabular}


Table A3: Source of data

\begin{tabular}{|l|c|c|}
\hline Variables & Description & Source \\
\hline$t k l$ & Effective capital labor tax ratio & $\begin{array}{c}\text { OECD revenue statistics, STAN, } \\
\text { National Accounts, Carey and } \\
\text { Rabesona (2002) }\end{array}$ \\
\hline social & $\begin{array}{c}\text { Social benefits and transfers in } \\
\text { percentage of GDP }\end{array}$ & OECD National Accounts \\
\hline lfpr & Labor force participation rate & OECD Economic Outlook \\
\hline open & KOF economics index & $\begin{array}{c}\text { Swiss federal institution of } \\
\text { technology, Zrich }\end{array}$ \\
\hline ygap & RGDP detrended by HP filtering & OECD Economic Outlook \\
\hline
\end{tabular}


Table A4: Country list and subsample classification for the 26 OECD countries

\begin{tabular}{|c|c|c|}
\hline Country & $\mathbf{E U}$ & Strong Capital Controls \\
\hline \multicolumn{3}{|l|}{ Australia } \\
\hline Austria & ○ & ○ \\
\hline Belgium & ○ & $\circ$ \\
\hline \multicolumn{3}{|l|}{ Canada } \\
\hline Czech, Rep. & ○ & ○ \\
\hline Denmark & $\circ$ & \\
\hline Finland & ○ & \\
\hline France & 0 & \\
\hline Germany & $\circ$ & \\
\hline Greece & ○ & ○ \\
\hline Ireland & 0 & \\
\hline Italy & O & \\
\hline Japan & & ○ \\
\hline Korea, Rep. & & 0 \\
\hline Netherlands & ○ & \\
\hline \multicolumn{3}{|l|}{ New Zealand } \\
\hline Norway & & ○ \\
\hline Poland & ○ & ○ \\
\hline Portugal & 0 & ○ \\
\hline Slovak, Rep. & 0 & 0 \\
\hline Slovenia & ○ & ○ \\
\hline Spain & $\circ$ & ○ \\
\hline Sweden & 0 & 0 \\
\hline \multicolumn{3}{|l|}{ Switzerland } \\
\hline United Kingdom & 0 & \\
\hline \multicolumn{3}{|l|}{ United States } \\
\hline & 18 & 13 \\
\hline
\end{tabular}


Table A5: Average index of capital control indicators during 1996 2011

\begin{tabular}{|c|c|c|c|}
\hline Weak & Average Index & Strong & Average index \\
\hline AUT & 2.439 & PRT & 2.422 \\
\hline CAN & 2.439 & SWE & 2.422 \\
\hline DEN & 2.439 & ESP & 2.389 \\
\hline FRA & 2.439 & JAP & 2.373 \\
\hline FIN & 2.439 & NOR & 2.340 \\
\hline GER & 2.439 & BEL & 2.191 \\
\hline IRL & 2.439 & GRC & 1.878 \\
\hline ITA & 2.439 & CZE & 1.559 \\
\hline NLD & 2.439 & AUS & 1.285 \\
\hline NZL & 2.439 & SVN & 1.158 \\
\hline CHE & 2.439 & SVK & -.063 \\
\hline GBR & 2.439 & KOR & -.212 \\
\hline USA & 2.439 & POL & -.398 \\
\hline Average & 2.439 & Average & 1.488 \\
\hline
\end{tabular}

